\title{
STRUCTURAL CHANGES IN THE PANCREAS OF EXPERIMENTAL DIABETIC RATS UNDER THE EFFECT OF SOME HYPOGLYCEMIC MEDICINAL PLANTS
}

\author{
Ashraf M. Moustafa* Eman G. E. Helal** Anwar Al-Kamel Mohamed** \\ Department of Histology, Faculty of Medicine* and Zoology Department Faculty of \\ Science (Girls)** \\ Al-Azhar University
}

\begin{abstract}
Background: Diabetes is a chronic metabolic disease which affects large number of population all over the world. Such disease is associated with many complications which may leads finally to patient's mortality. More than 400 traditional medicinal plants have been recorded for helping in controlling such disease. So this study was planned to evaluate the effect of one of the famous plant mixture used in Saudi Arabia and some other Arab countries as hypoglycemic agent.

Material and methods: Fourty adult male Albino Rats were divided into 8 experimental groups: The first group was considered as a control group. The rest of groups were affected by induction of experimental diabetes by subcutaneous injection of Alloxan. The second group was consisted of diabetic rats without any treatment.The third group was treated by water mixture of the plants used. The fourth group treated with Nigella sativa while the fifth group treated with Aloe vera. The sixth one treated with Feruls assa foetida. The seventh group was treated with Boswellia carterii Birdw and finally the last group was treated with Commiphora myrrha. The used plant dose was $1 \mathrm{ml} / 100 \mathrm{gm}$ body weight. After four weeks of treatment different physiological parameters were performed including estimation of the body weight, blood sugar level and serum insulin level. Pancreatic samples were obtained and processed for microscopic and quantitative evaluation after staining the prepared sections with both Heamatoxylin and eosin as well as special stain for demonstration of the different pancreatic cells in the Islet of the Langerhans.

Results: The obtained results showed that the induced diabetes was diagnosed by laboratory assessment. The usage of the mixture or each plant alone was correct the glucose level,body weight gain and the insulin level. Microscopically there was definite decrease in the number and diameter of beta pancreatic cells in the diabetic group while the other pancreatic cells were not affected (alpha and delta cells).

The use of medicinal plants in the different groups of this study greatly improves such cellular changes and the level of blood sugar level was corrected. The results obtained by the use of Commiphora myrrha was the best when compared with the rest of other plants. Delta cells were reduced in number and diameter with such treatment.

Conclusions: It is recommended from such study that the use of the plant mixture as a hypoglycemic agent may be of good results than the use of each plant separately besides repeating such study with the use of variable doses may be helpful in better evaluation for the required doses.
\end{abstract}

Key words: Alloxan - Hypoglyceamia - Diabetes - Pancreas

\section{INTRODUCTION}

$\begin{array}{ccc}\text { Diabetes } & \text { mellitus } & \text { affects } \\ \text { approximately } & 100 & \text { million } \\ \text { persons }\end{array}$ worldwide (Amos et al., 1997). Five to ten percent have type 1 (formerly known as insulin-dependant) and $90 \%$ to $95 \%$ have type 2 (non-insulin-dependant) diabetes 
mellitus. It is likely that the incidence of type 2 diabetes will rise as a consequence of lifestyle patterns contributing to obesity (Meral et al., 2004). The pathogenesis of hyperglycemia in type 2 diabetes involves defects in both pancreatic secretory function and insulin sensitivity .

Diabetes is possibly the world's fastest growing metabolic disease, and as the knowledge of the heterogencity of this disorder increases, so does the need for more appropriate therapies (Baily and Flott, 1986).

Traditional herbal remedies which are often free from side effects are still in use by diabetic patients, especially in third world countries and may therefore, present new avenues in the search for alternative hypoglycemic drugs (Ajagaokar, 1979) and such remedies are used in treatment of diabetes in developing countries. The actual medicinal action of plant drug lies in its active constituents such as alkaloids, cardiac glycosides saponins, flavonoids, volatel oils, terpenoids, resin and mucilage. Many investigators reported that folk medicine in Egypt had described 25 kinds of Egyptian herbs and plants prescriptions belonging to 13 families to be concerned with the treatment of diabetes mellitus (Mossa, 1985).

Nigella sativa is a medical plant used for treating many diseases such as rheumatism and cancer . The essential oil of Nigella sativa exhibits hypo-glycemic and bronchodilator properties (AL-Hader et al., 1993). In the lpresent work, water extract of a mixture composed of five plants was proved to have a good hypoglycemic effect on diabetic rats; Nigella sativa was one component of this mixture. So, this study was designed to follow up the action of $a$ mixture water extract or each plant alone treatment and to show whether it has an insulin like-action or it may accelerate insulin secretion from pancreatic cells. Also the study aims at revealing its effects on the pancreatic cell type and numbers.

Diabetes is possibly the world's fastest growing metabolic disease, and as knowledge of heterogencity of this disorder increases, so does the need for more appropriate therapies (Baily and Flott, 1986).
Traditional antidiabetic plants might provide useful source of new oral hypoglycemic compounds for development countries as pharmaceutical entities, or as simple dietary adjuncts to existing therapies. A scientific investigation of traditional herbal remedies for diabetes mellitus may be valuable and leads to development of an alternative drugs and therapeutic strategies. Alternatives are clearly needed because of the inability of current therapies to control high cost and poor availability of current therapies for many rural populations, particularly in developing countries (Marles and Farnsworth, 1995).

Alloxan and streptozotocin (STZ) were found to be selectively $\beta$-cytotoxic agents in animals and extremely potent diabetogenic substances (Rakieten et al., 1963), so alloxan and STZ have been widely used to produce diabetes in experimental animals (Okamoto, 1984).

Commiphora myrrha (Myrrh) Family (Burseraceae) is native to Northeastern Africa, especially Somalia. Myrrh is one of the oldest known medicines and was widely used by the ancient Egyptians. It is an excellent remedy for mouth and throat problems, with a drying, slightly bitter taste, and it also useful for skin problems, atherosclerosis, hemorrhoid, heptoses, high cholesterol, stomatosis, immunodepression and hyperglycemia. The myrrh's Gumresin-volatile oil are the main used parts, where it contains (30-60\%) gum including acidic polysaccharides, resin(25-40\%), volatile oil (3-8\%), heerabolene, eugenol and many furansesquiterpenes (Chevallier, 1996 and Duke, 2002).

The present study was also a trial to clarify the effect of some medicinal plants as hypoglycemic agent and their effect on different cells of islet of Langerhans.

\section{MATERIAL AND METHODS Material:}

A-Animals: Forty adult male albino rats of local strain with body weight ranging between (120-140 gm) were used in the current work. Rats were divided into eight equal groups:

Group I (Control group), were given subcutaneous (s.c.) saline solution 
(0.01 ml / 100gm b.wt.).

Group II (Diabetic group), were given s.c alloxan (120 mg / kg b. wt.) for induction of diabetes mellitus (Dunn et al., 1943).

The rest of the groups were diabetic and treated as follows:

Group III treated with the mixture of the tested plants. $(0.1 \mathrm{gm} / 100 \mathrm{gm}$ body weight)

Group IV treated with Nigella sativa.

Group V treated with Aloe vera.

Group VI treated with Ferula assa-foetida.

Group VII treated with Boswellia caterii Birdw.

Group VIII treated with Commiphora myrrha.

All groups were sacrified after 4 weeks.

\section{B-Drugs and chemicals:}

Alloxan (powder from B.D.H chemical

LTD,England), dissolved in acetate

buffer ( $\mathrm{pH}$ 5.5) prepared immediately

before use.

\section{Methods:}

-Induction of diabetes mellitus: By giving subcutaneous injection freshly prepared alloxan solution $120 \mathrm{mg} / \mathrm{kg}$ after an overnight fasting of the animals then 48 hours later blood glucose level was determined by glocometer. Rats with blood glucose level ranging from 180 to 250 were considered diabetic (Dunn et al., 1943).

Three main laboratory parameters were done including estimation of the animal body weight, level of blood sugar ( Tietz 1986) and the serum level of insulin (Reeves 1983).

The samples of pancreas were obtained and processed for preparation of paraffin sections. Two types of stains were used, Hematoxylin \& Eosin (HX\&E) for morphological changes and Modified aldehyde fuchsin stain (Halami, 1952)for identification of different cellular elements in the Islet of langerhans.

Image analysis system was used for determination alpha, beta and delta cells number and diameters in the islet of Langerhans.

Data were analyzed using student $(\mathrm{t})$ test, significant differences between the means of control and treated groups were considered at p $<0.05$ (Sokal and Rohif, 1981)

\section{RESULTS}

\section{Physiological changes:}

\section{1- Changes in the body weight (Table 1}

, Fig. 1 )

Highly significant decrease in the body weight in the diabetic and Nigella sativa treated group. Significant increase in the weight was recorded in the group treated by Ferula assa-foetida.

Insignificant change in the weight was observed in other groups of the study.

\section{2- Changes in the serum glucose level (}

\section{Table 2 , Fig. 2 )}

Marked increase in the serum level of glucose was recorded in the diabetic group. All the treated groups showed insignificant changes when compared with the control rats.

\section{3- Changes in the serum insulin level(}

\section{Table 3 , Fig. 3 )}

Marked hypoinsulinemia was recorded in the diabetic group when compared to the control group. All other treated groups showed insignificant changes when compared with the control group.

\section{Histological changes: ( Figs.10-25)}

Insignificant changes was noticed in the number and diameter of the alpha cells in both diabetic and treated groups during the experimentation.

There was reduction in the number of beta cells beside cellular changes in the form of vacuolation. The diameter of beta cells was somewhat increased mainly in the diabetic group.

Treated groups showed improvement in both number and diameter of the beta cells. The vacuolation and degranulation are much improved.

No changes were recorded in the number and diameter of the delta cells in both control and Aloe vera treated groups.

All other groups showed significant decrease in the delta cells number as well as diameter.

The morphometric changes in this study were tabulated and statistically analysed in tables ( 4-9) and Figures (4-9). 
(Table 1 ) Changes in the $\%$ of body weight gain in the different groups of the study

\begin{tabular}{|c|c|c|c|c|c|c|c|c|c|}
\hline & \multicolumn{8}{|c|}{ Treatment period } \\
\hline & & Control & Diabetic & Mixture & $\begin{array}{l}\text { Nigella } \\
\text { Sativa }\end{array}$ & $\begin{array}{l}\text { Aloe } \\
\text { vera }\end{array}$ & $\begin{array}{c}\text { Ferula } \\
\text { asaa- } \\
\text { foetida }\end{array}$ & $\begin{array}{c}\text { Boswellia } \\
\text { carterii } \\
\text { Brdw }\end{array}$ & $\begin{array}{c}\text { Commiph } \\
\text { ora } \\
\text { myrrha }\end{array}$ \\
\hline \multirow{4}{*}{ 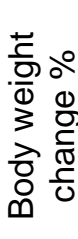 } & Mean & 35.99 & 9.42 & 33.78 & 23.52 & 37.39 & 55.72 & 40.72 & 40.04 \\
\hline & SD & 1.02 & 0.96 & 1.84 & 0.82 & 0.37 & 0.77 & 0.95 & 0.49 \\
\hline & A & & ** & & ** & & ** & * & ** \\
\hline & B & & & ** & ** & ** & ** & ** & ** \\
\hline
\end{tabular}

(Table 2 ) Changes in the serum glucose level of the different groups of the study

\begin{tabular}{|c|c|c|c|c|c|c|c|c|c|}
\hline & \multicolumn{8}{|c|}{ Treatment period } \\
\hline & & Control & Diabetic & Mixture & $\begin{array}{l}\text { Nigella } \\
\text { Sativa }\end{array}$ & $\begin{array}{l}\text { Aloe } \\
\text { vera }\end{array}$ & $\begin{array}{c}\text { Ferula } \\
\text { asaa- } \\
\text { foetida }\end{array}$ & $\begin{array}{l}\text { Boswellia } \\
\text { carterii } \\
\text { Brdw }\end{array}$ & $\begin{array}{l}\text { Commiph } \\
\text { ora myrrha }\end{array}$ \\
\hline \multirow{4}{*}{ 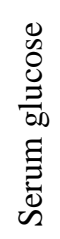 } & Mean & 136.8 & 266.8 & 134.8 & 131.2 & 139.2 & 135.0 & 137.8 & 135.6 \\
\hline & SD & 0.86 & 0.41 & 0.37 & 1.99 & 0.75 & 0.32 & $0 . .58$ & 0.51 \\
\hline & A & & ** & & & & & & \\
\hline & B & & & ** & ** & ** & ** & ** & ** \\
\hline
\end{tabular}

(Table 3 ) Changes in the serum insulin level in the different groups of the study

\begin{tabular}{|c|c|c|c|c|c|c|c|c|c|}
\hline & \multicolumn{8}{|c|}{ Treatment period } \\
\hline & & Control & Diabetic & Mixture & $\begin{array}{l}\text { Nigella } \\
\text { Sativa }\end{array}$ & $\begin{array}{l}\text { Aloe } \\
\text { vera }\end{array}$ & $\begin{array}{l}\text { Ferula } \\
\text { asaa- } \\
\text { foetida }\end{array}$ & $\begin{array}{l}\text { Boswellia } \\
\text { carterii } \\
\text { Brdw }\end{array}$ & $\begin{array}{l}\text { Commiph } \\
\text { ora myrrha }\end{array}$ \\
\hline \multirow{4}{*}{ 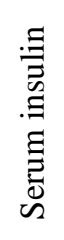 } & Mean & 41.60 & 20.60 & 41.00 & 32.40 & 39.20 & 25.60 & 37.60 & 39.70 \\
\hline & SD & 1.51 & 1.81 & 1.22 & 1.44 & 1.32 & 1.57 & 1.51 & 1.60 \\
\hline & A & & ** & & ** & & ** & & \\
\hline & B & & & ** & ** & ** & ** & ** & ** \\
\hline
\end{tabular}

A- In comparison to the control group

B- In comparison to the diabetic group 


\section{Ashraf M. Moustafa et al}

(Table 4) Changes in the number of alpha cells in the different groups.

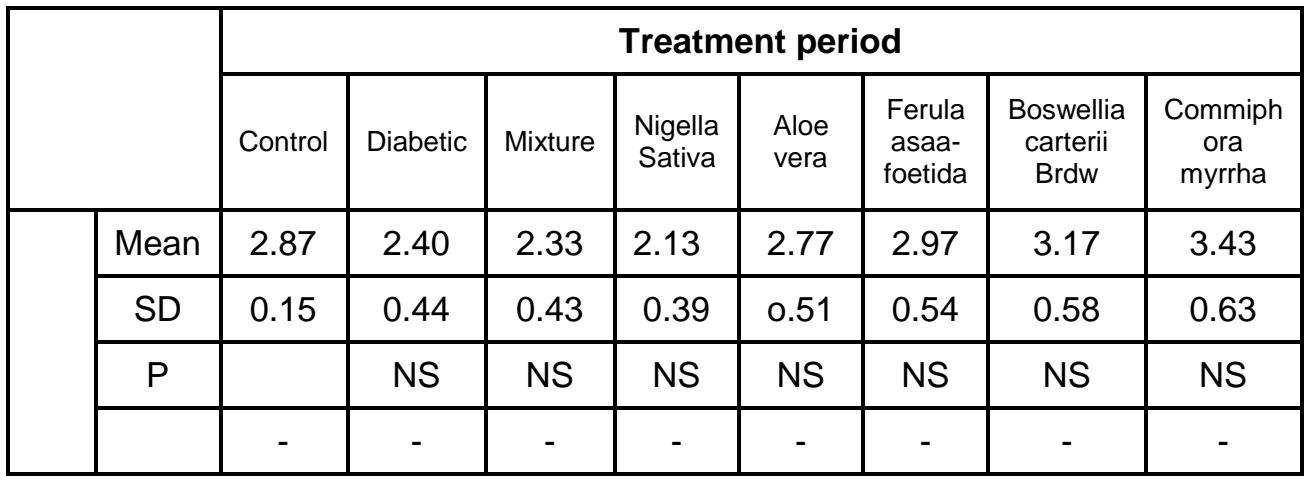

(Table 5 ) Changes in the number of beta cells in the different groups.

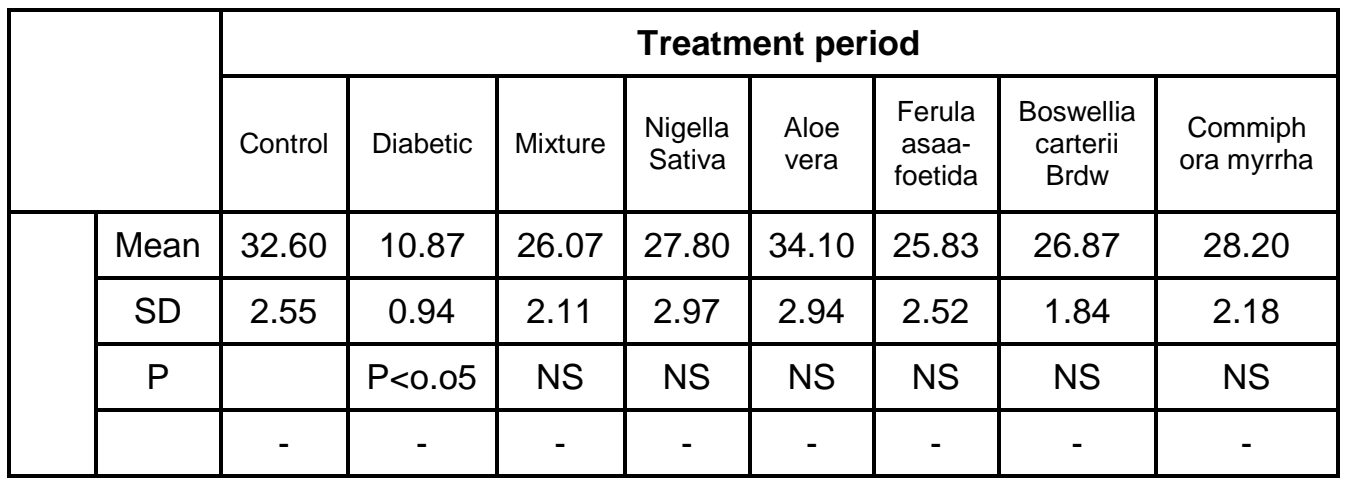

(Table 6 ) Changes in the number of delta cells in the different groups.

\begin{tabular}{|c|c|c|c|c|c|c|c|c|}
\hline & \multicolumn{8}{|c|}{ Treatment period } \\
\hline & Control & Diabetic & Mixture & $\begin{array}{l}\text { Nigella } \\
\text { Sativa }\end{array}$ & $\begin{array}{l}\text { Aloe } \\
\text { vera }\end{array}$ & $\begin{array}{c}\text { Ferula } \\
\text { asaa- } \\
\text { foetida }\end{array}$ & $\begin{array}{c}\text { Boswellia } \\
\text { carterii } \\
\text { Brdw }\end{array}$ & $\begin{array}{l}\text { Commiph } \\
\text { ora myrrha }\end{array}$ \\
\hline Mean & 3.50 & 3.60 & 2.64 & 2.73 & 3.17 & 2.80 & 3.83 & 2.73 \\
\hline SD & 0.18 & 0.21 & 0.17 & 0.16 & 0.21 & 0.23 & 0.27 & 0.21 \\
\hline$P$ & & NS & $P<0.05$ & $P<0.05$ & NS & $P<0.05$ & NS & $P<0.05$ \\
\hline & - & - & - & - & - & - & - & - \\
\hline
\end{tabular}


Structural Changes In The Pancreas Of.....

(Table 7 ) Changes in the diameter of alpha cells in the different groups.

\begin{tabular}{|c|c|c|c|c|c|c|c|c|}
\hline & \multicolumn{8}{|c|}{ Treatment period } \\
\hline & Control & Diabetic & Mixture & $\begin{array}{l}\text { Nigella } \\
\text { Sativa }\end{array}$ & $\begin{array}{l}\text { Aloe } \\
\text { vera }\end{array}$ & $\begin{array}{l}\text { Ferula } \\
\text { asaa- } \\
\text { foetida }\end{array}$ & $\begin{array}{c}\text { Boswellia } \\
\text { carterii } \\
\text { Brdw }\end{array}$ & $\begin{array}{c}\text { Commiph } \\
\text { ora } \\
\text { myrrha }\end{array}$ \\
\hline Mean & 3.03 & 3.48 & 2.88 & 3.15 & 3.15 & 2.96 & 2.86 & 2.91 \\
\hline SD & 0.11 & 0.14 & 0.10 & 0.17 & 0.13 & 0.13 & 0.14 & 0.12 \\
\hline$P$ & & NS & NS & NS & NS & NS & NS & NS \\
\hline & - & - & - & - & - & - & - & - \\
\hline
\end{tabular}

(Table 8 ) Changes in the diameter of beta cells in the different groups.

\begin{tabular}{|c|c|c|c|c|c|c|c|c|}
\hline & \multicolumn{8}{|c|}{ Treatment period } \\
\hline & Control & Diabetic & Mixture & $\begin{array}{l}\text { Nigella } \\
\text { Sativa }\end{array}$ & $\begin{array}{l}\text { Aloe } \\
\text { vera }\end{array}$ & $\begin{array}{c}\text { Ferula } \\
\text { asaa- } \\
\text { foetida }\end{array}$ & $\begin{array}{c}\text { Boswellia } \\
\text { carterii } \\
\text { Brdw }\end{array}$ & $\begin{array}{l}\text { Commiph } \\
\text { ora myrrha }\end{array}$ \\
\hline Mean & 3.25 & 4.49 & 3.02 & 2.85 & 3.06 & 2.81 & 2.83 & 3.00 \\
\hline SD & 0.15 & 0.14 & 0.19 & 0.18 & 0.19 & 0.17 & 0.17 & 0.12 \\
\hline$P$ & & $P<0.05$ & NS & NS & NS & NS & NS & NS \\
\hline & - & - & - & - & - & - & - & - \\
\hline
\end{tabular}

(Table 9 ) Changes in the diameter of delta cells in the different groups.

\begin{tabular}{|c|c|c|c|c|c|c|c|c|}
\hline & \multicolumn{8}{|c|}{ Treatment period } \\
\hline & Control & Diabetic & Mixture & $\begin{array}{l}\text { Nigella } \\
\text { Sativa }\end{array}$ & $\begin{array}{l}\text { Aloe } \\
\text { vera }\end{array}$ & $\begin{array}{l}\text { Ferula } \\
\text { asaa- } \\
\text { foetida }\end{array}$ & $\begin{array}{c}\text { Boswellia } \\
\text { carterii } \\
\text { Brdw }\end{array}$ & $\begin{array}{l}\text { Commiph } \\
\text { ora myrrha }\end{array}$ \\
\hline Mean & 3.85 & 3.54 & 3.33 & 3.25 & 3.75 & 3.23 & 3.63 & 2.98 \\
\hline SD & 0.11 & 0.11 & 0.18 & 0.12 & 0.09 & 0.13 & 0.12 & 0,12 \\
\hline$P$ & & NS & $P<0.05$ & $P<0.05$ & NS & $P<0.05$ & NS & $P<0.05$ \\
\hline & - & - & - & - & - & - & - & - \\
\hline
\end{tabular}


Fig 1

\section{Changes in the \% of body weight in the different groups of the study}

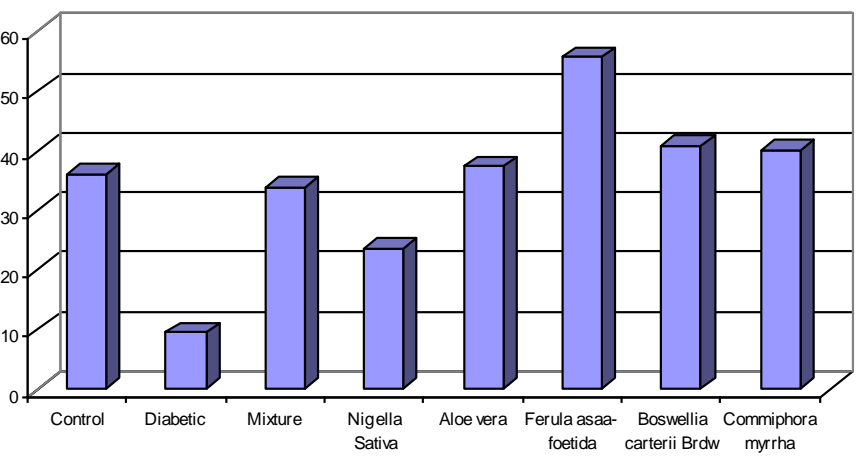

\section{Changes in the serum glucose level(mg/dl) in the different groups of the study}

Fig 2

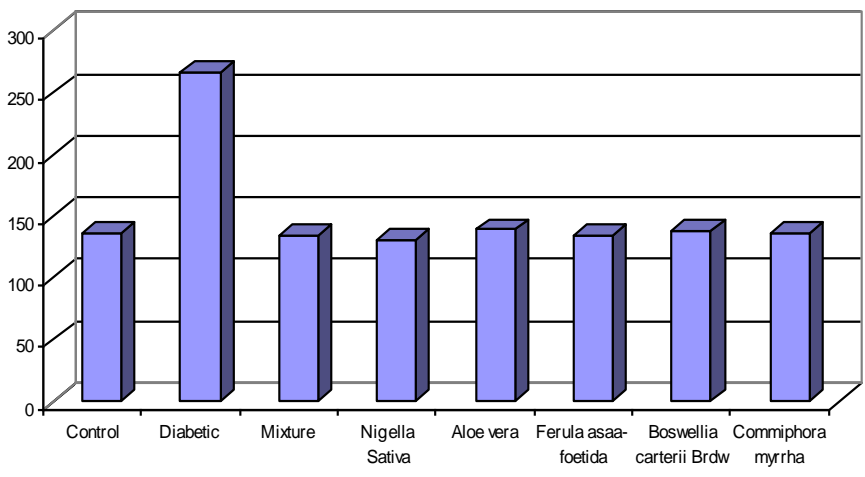

Fig 3

\section{Changes in the serum insulin level in the different groups of the study}

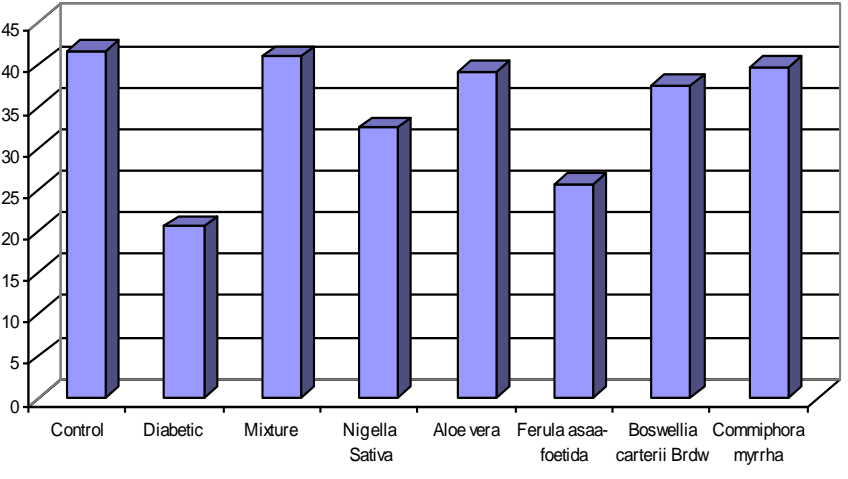


STRUCTURAL CHANGES IN THE PANCREAS OF.....

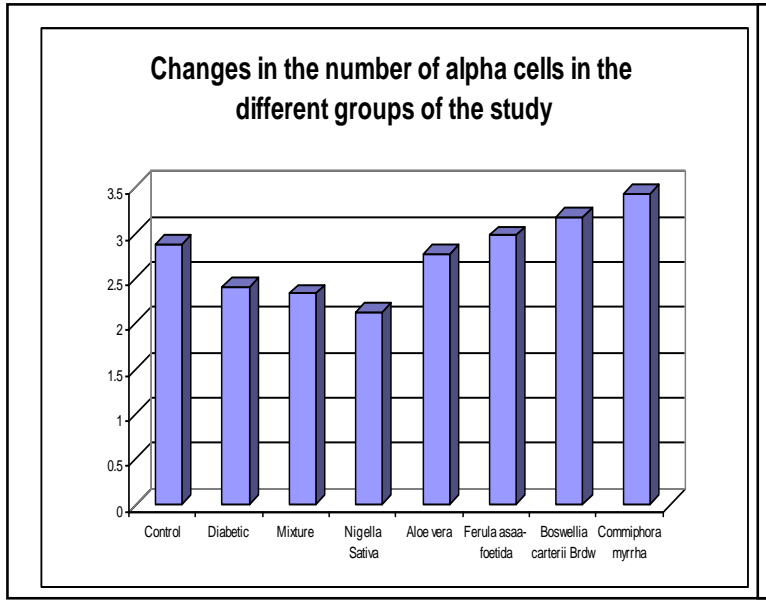

Fig. 4

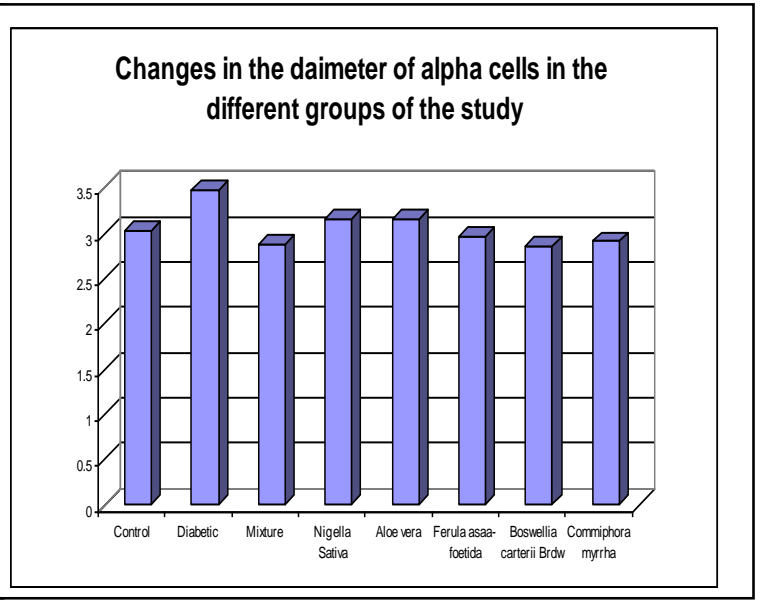

Fig. 5

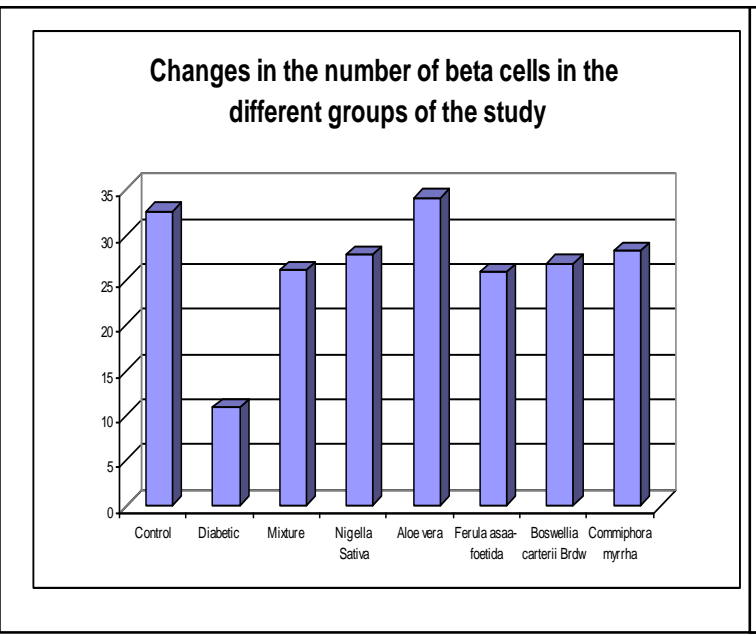

Fig. 6

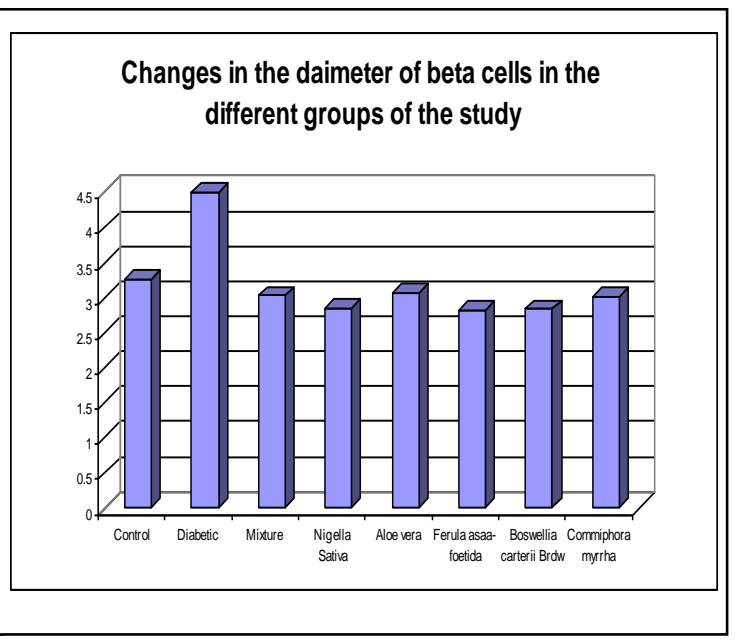

Fig. 7

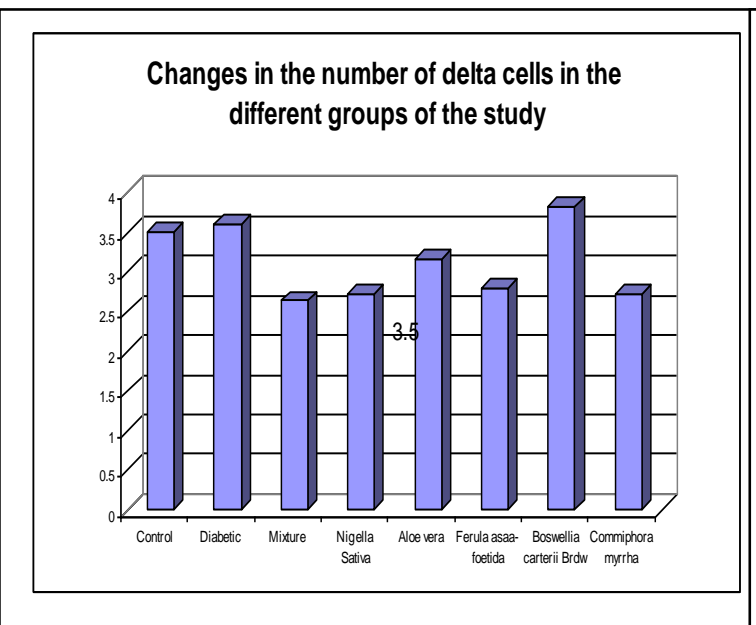

Fig. 8

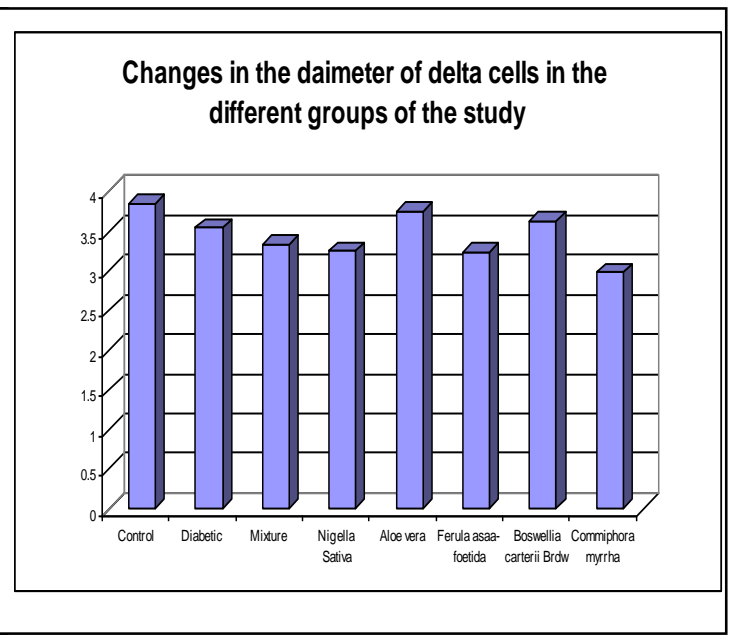

Fig. 9 


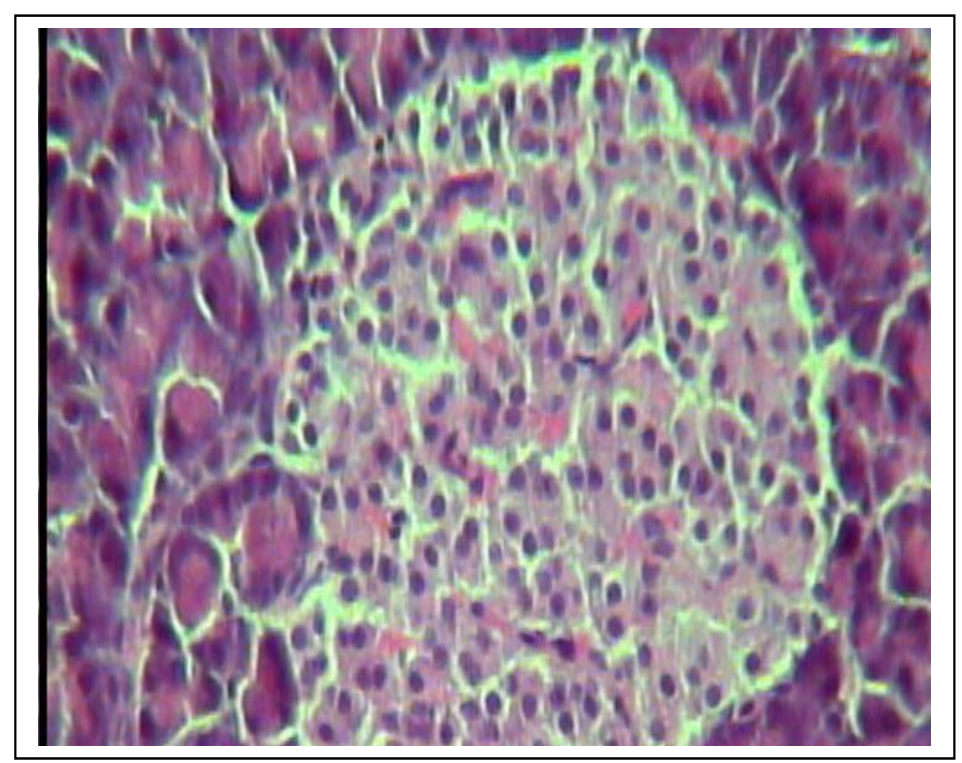

Fig. 10 Photomicrograph of control section in the Islet of langerhans showing the different cellular elements. ( Hx.\&E stain X 400)

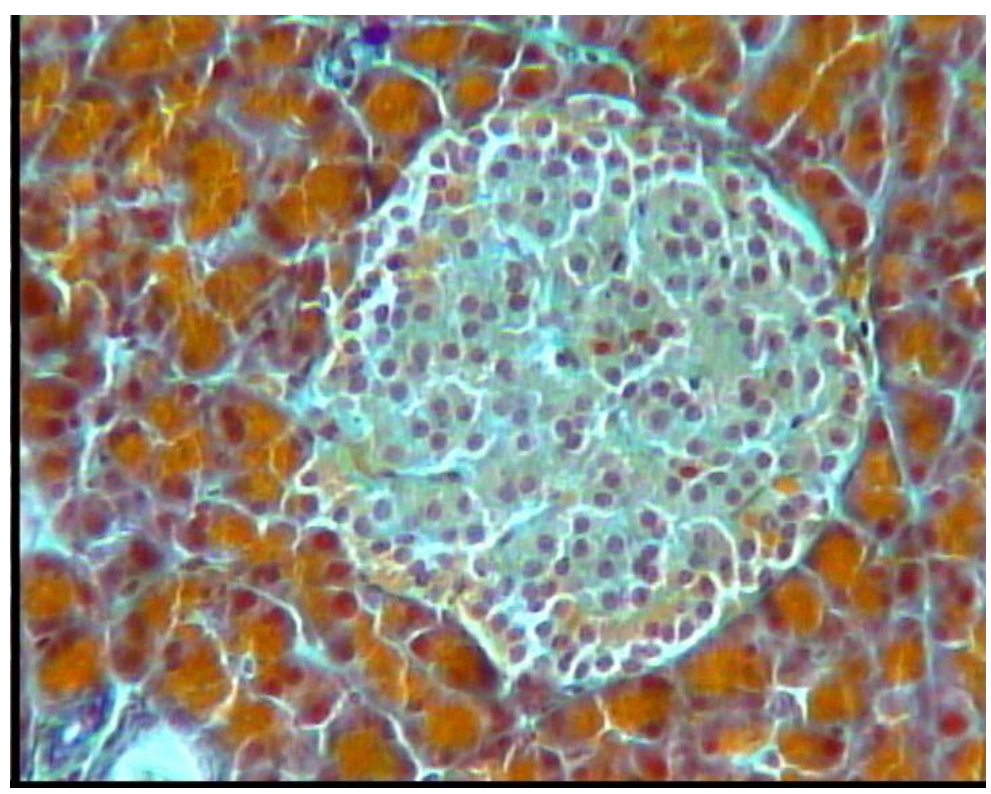

Fig. 11 Photomicrograph of control section in the Islet of langerhans showing the different cellular elements.

( Modified aldehyde fuchsin stain X 400 ) 


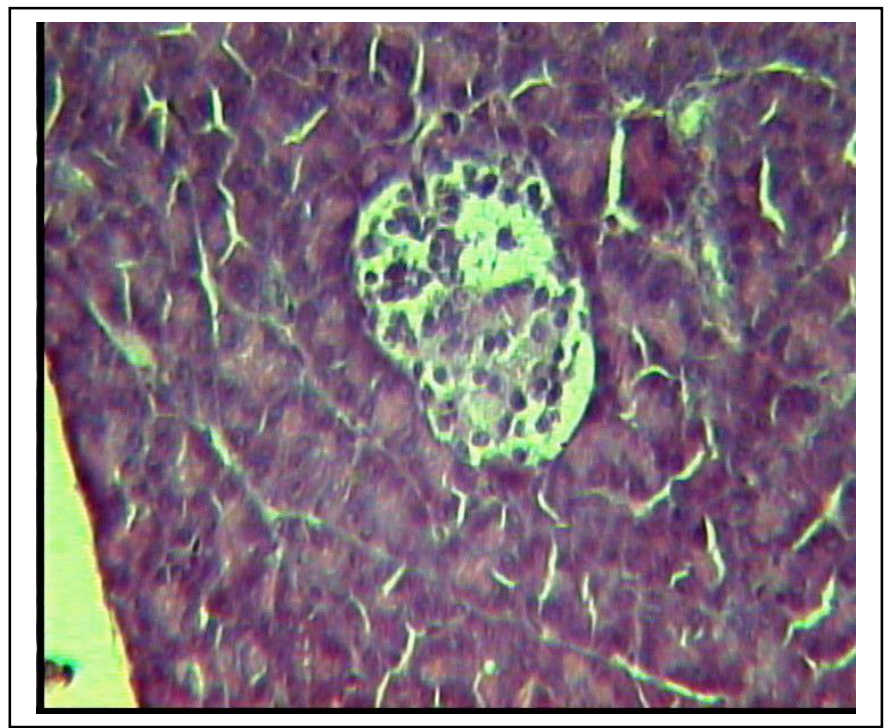

(Fig. 12) A photomicrograph if a section in the pancreas of a diabetic rats showing degenerated cells in the islet of Langerhans. (HX \& E X 400).

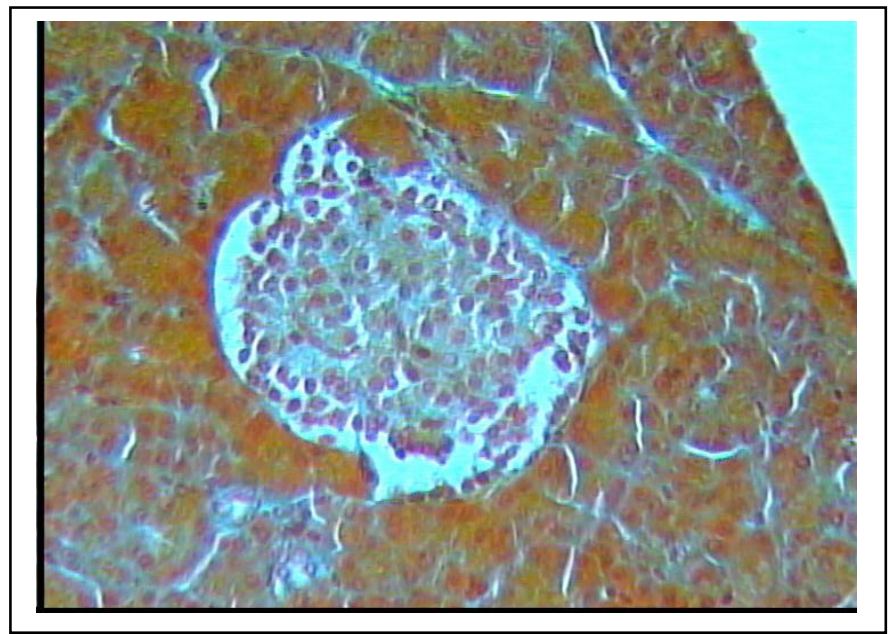

Fig. 13 Photomicrograph in the Islet of langerhans of diabetic rats showing the degenerative changes.

( Modified aldehyde fuchsin stain X 400) 

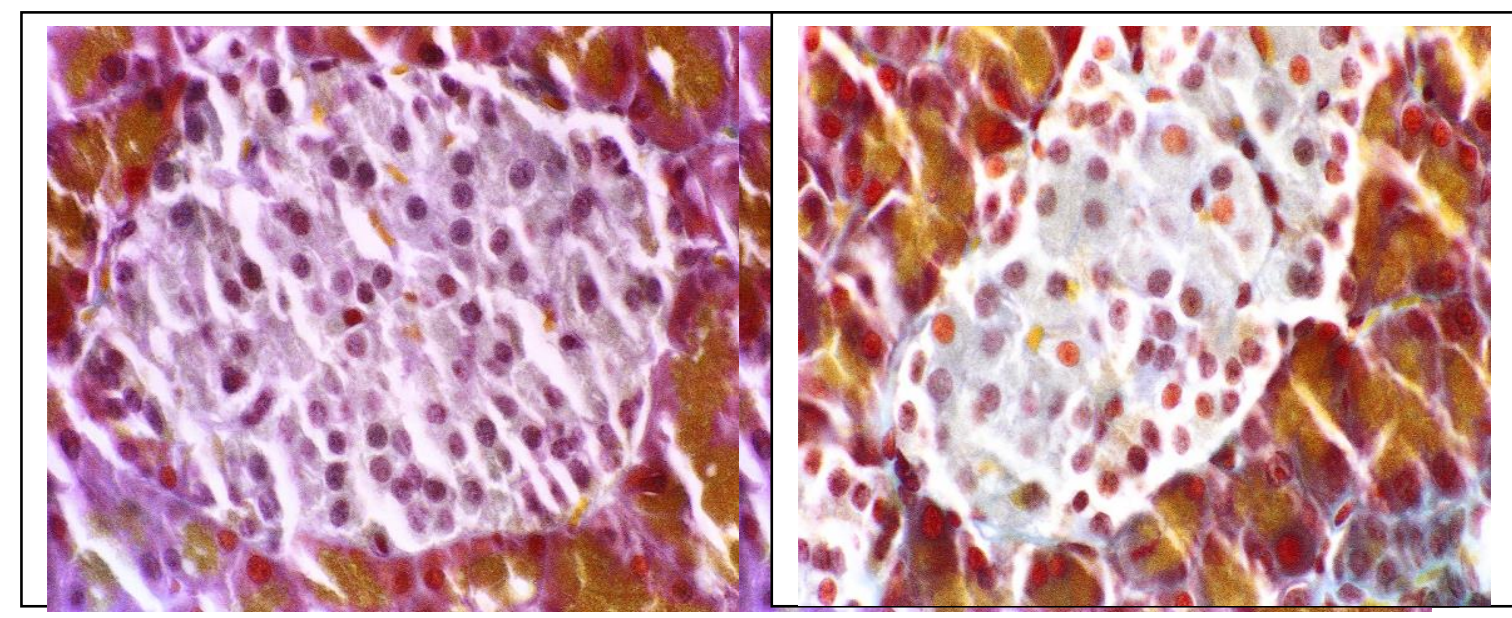

Fig.14 Section in the pancreas treated with the mixture showing less cellular vacuolationn and more healthy beta cells. ( Modified aldehyde fuchsin stain X 400 )

Fig. 15 Section in the pancreas treated with Nigella Sative showing healthy islet cells . ( Modified aldehyde fuchsin stain $\mathrm{X} 400$ )
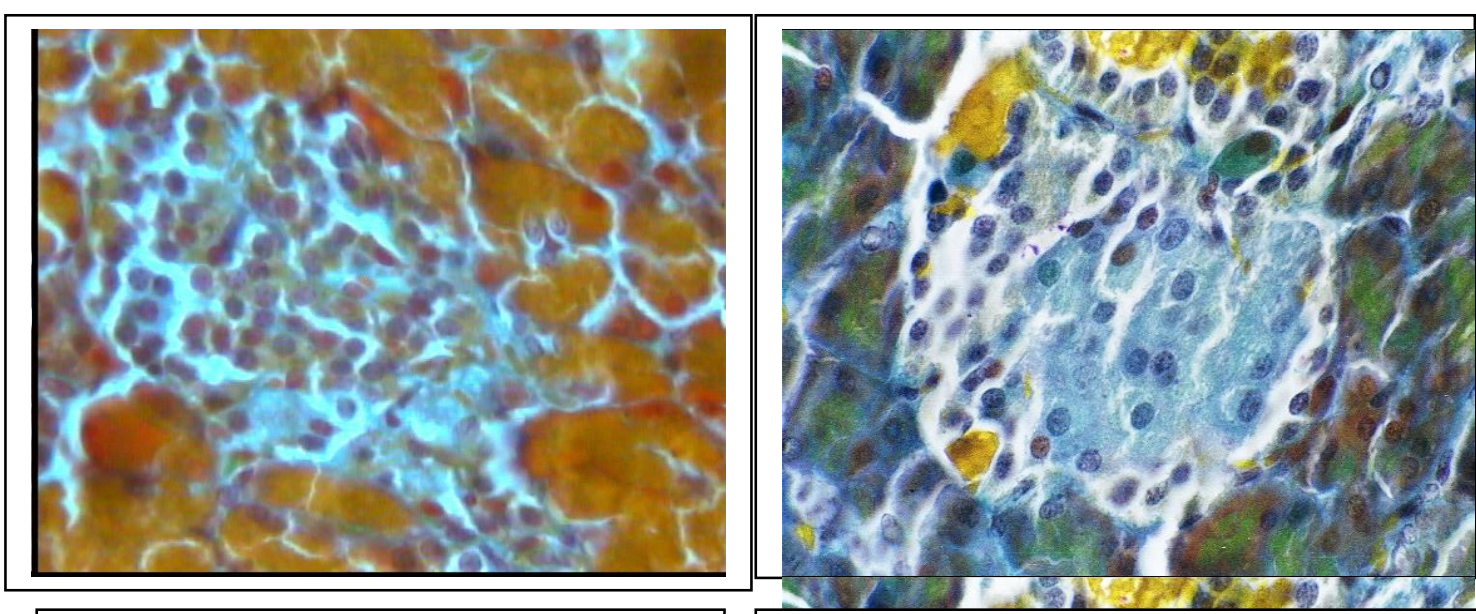

Fig. 16 Section in the pancreas treated with the Aloe Vera showing no observable celluar changes. ( Modified aldehyde fuchsin stain $X \quad 400$ )

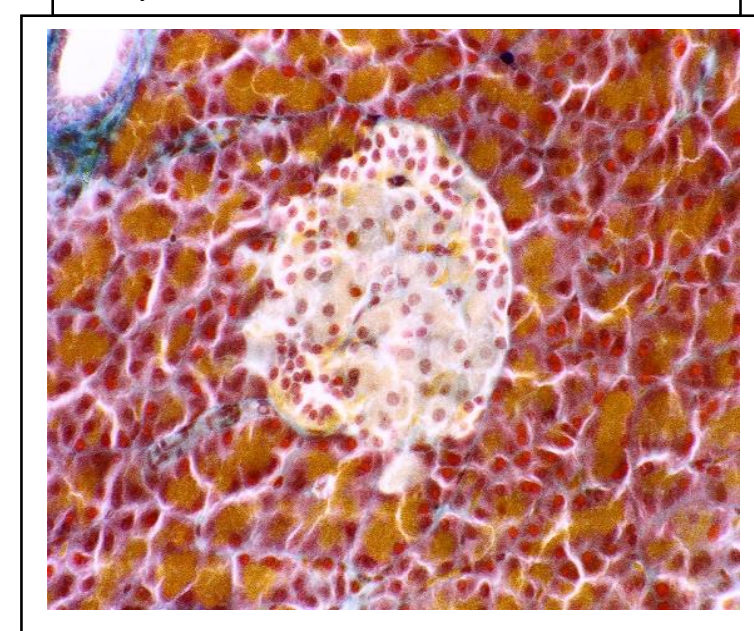

Fig. 17 Section in the pancreas treated with Ferula assa foetida showing less vacuolation and healthy beta cells. ( Modified aldehyde fuchsin stain X 400 )

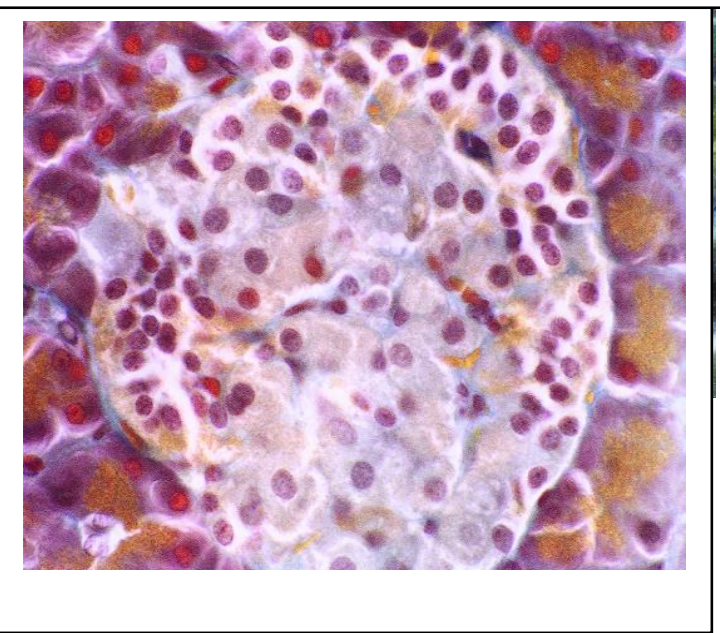

Fig. 18 Section in the pancreas treadted with Boswellia carterii Birdw showing normal islet cells. ( Modified aldehyde fuchsin stain $\quad$ X 400 )

Fig. 19 Section I the pancreas treadted with Commiphora myrrha showing normal islet cells. ( Modified aldehyde fuchsin stain $X 400$ ) 


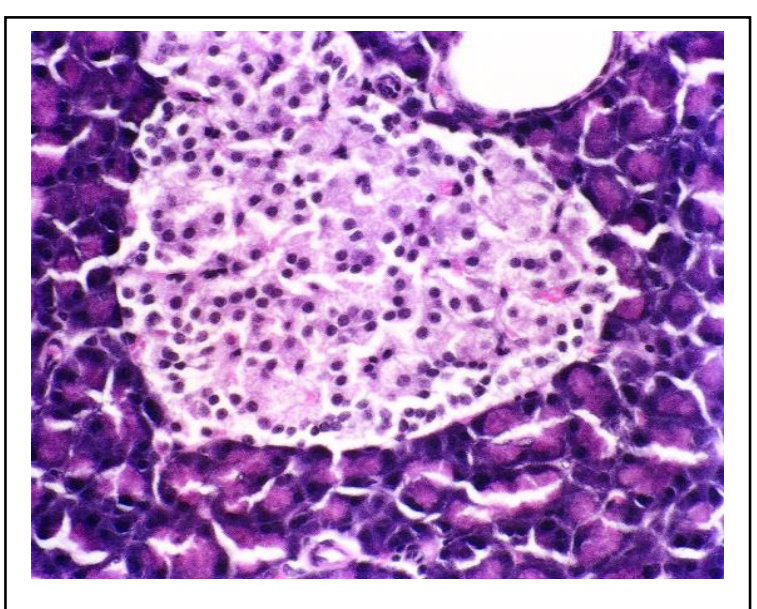

Fig.20 Section in the pancreas treated with the mixture showing less cellular vacuolationn and more healthy beta cells. ( Hx E stain X 400)

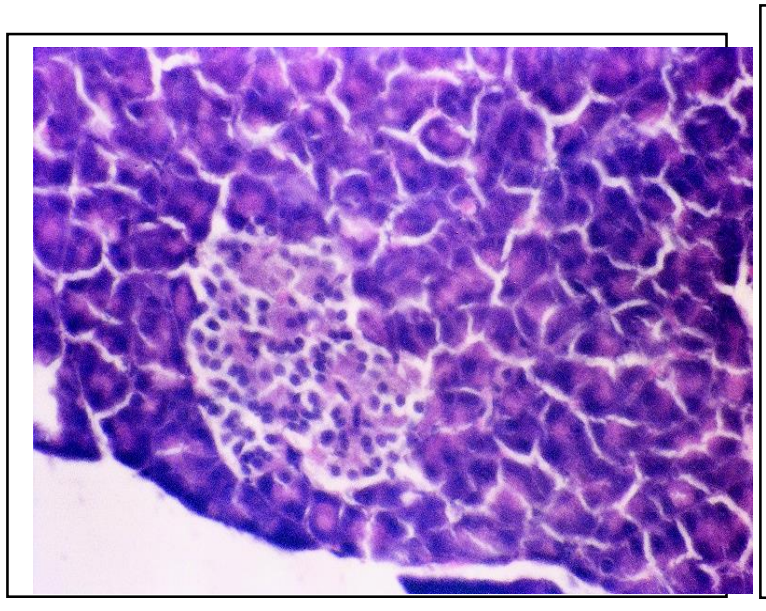

Fig. 22 Section in the pancreas treated with the Aloe Vera showing no observable celluar changes .

( Hx.E stain X 400)

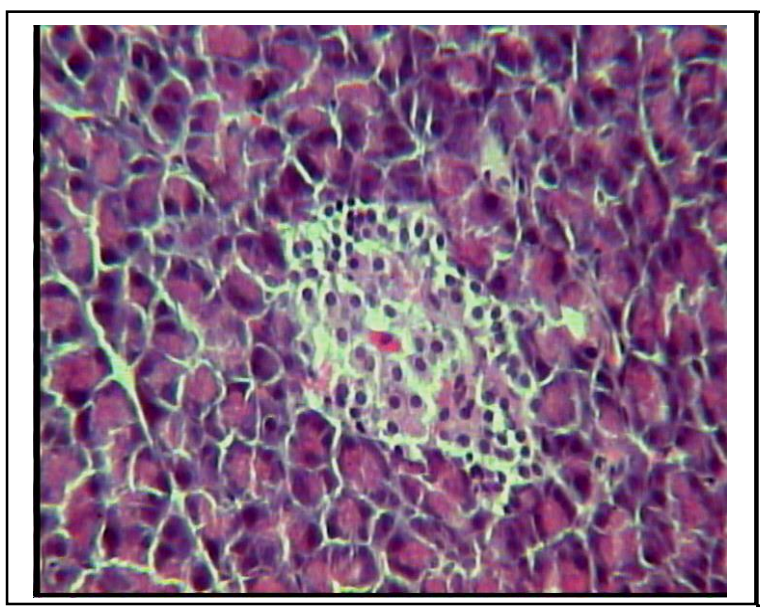

Fig. 24 Section in the pancreas treadted with Boswellia carterii Birdw showing normal islet cells.

( Hx.E stain X 400)

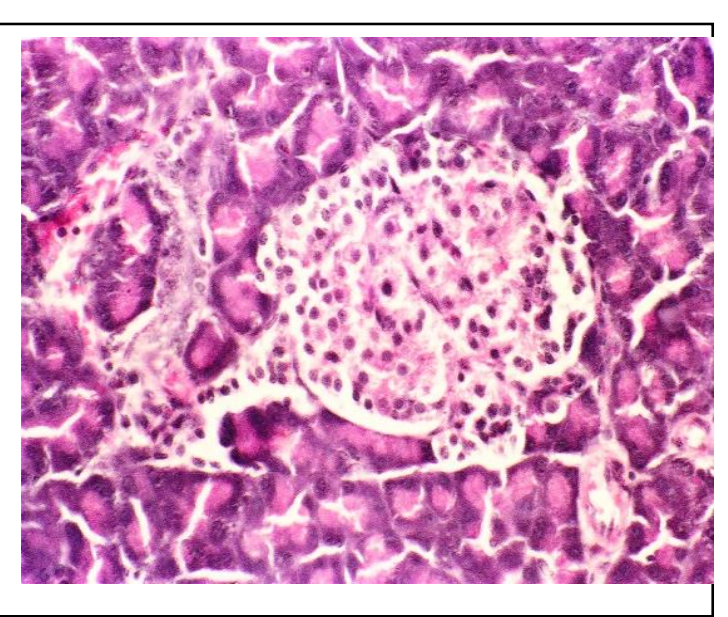
Fig. 21 Section in the pancreas treated with Nigella Sative showing healthy islet cells . ( Hx.E stain X 400)

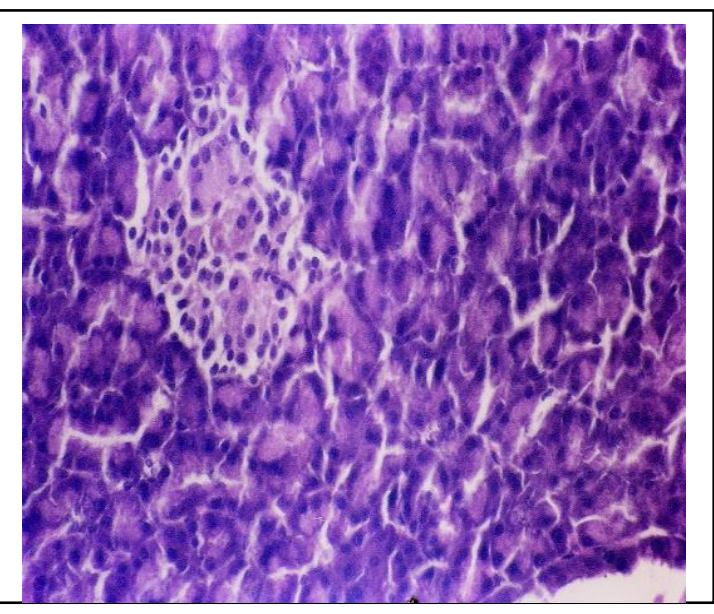

Fig. 23 Section in the pancreas treated with Ferula assa foetida showing less vacuolation and healthy beta cells ( Hx.E stain X 400)

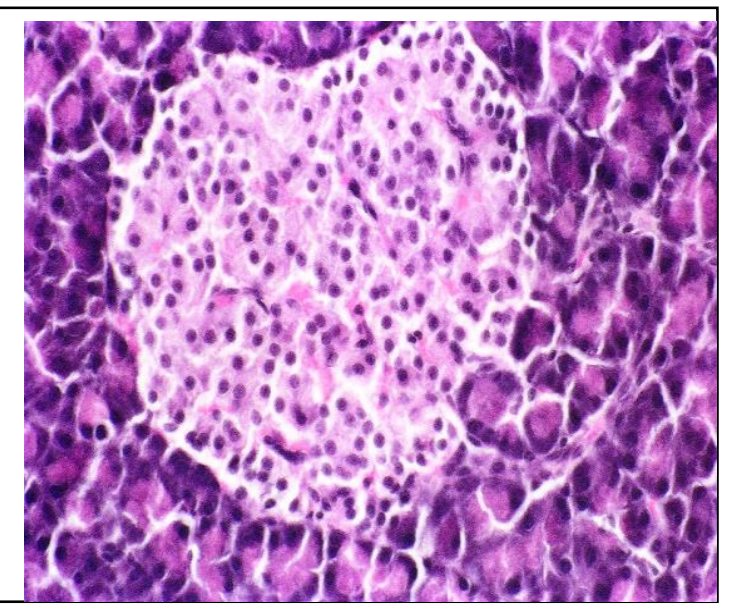

Fig. 25 Section I the pancreas treadted with Commiphora myrrha showing normal islet cells (Hx.E stain $\mathrm{X} 400$ ) 


\section{DISCUSSION}

The diabetic patients need alternative therapies to control all the pathological aspects of diabetes and the high cost and poor availability of current therapies in developing countries (Marles and Farnsworth, 1995).

The traditional antidiabetic plants might provide this useful source of new oral hypoglycemic compounds. So, this study is a step to evaluate and follow up the effect of some water extract of medicinal plants as a hypoglycemic agent.

The present results, revealed loss in body weight gain in diabetic rats when compared with the control rats. This loss may be explained by inhibition of synthesis of DNA and RNA in the diabetic animals or it is attributed to different side effects on the ability to use carbohydrates including lipolysis, glycogenolysis and acidosis. This result is mainly due to destructions of $\beta$ cells which lead to sudden drops of insulin secretion (Abdel-Moneim et al., 1999a; Ganong, 2003; Helal et al.,2003 and Rawi et al., 1996).

Our data also, showed an increase in the body weight gain in all treated groups when compared with diabetic one. The mixture may stimulate most aspects of carbohydrate metabolism, including rapid uptake of glucose by the cells, enhanced glycolysis, enhanced gluconeogenesis, increased rate of absorption from the gastrointestinal tract and even increased insulin secretion with its resultant secondary effects on carbohydrate metabolism (Guyton and Hall, 2000). Ferula assa-foetida, Boswellia carterii Birdw and Commiphora myrrha treated groups showed an increase in the body weight gain when compared with control group. This increase in the body weight gain may be due to the pervious suggestion in addition to the activities of these plants in strengthening the gastrointestinal tract by increasing both the rate of secretion of the digestive juices and the motility of the gastrointestinal tract (Guyton, and Hall, 2000), so they are taken for indigestion (Chevallier, 1996 and Duke, 2002) .
While, Nigella sativa treated group showed a decrease in the body weight gain when compared with control group. This probably rise from its claim to result in nutrient partitioning so that ingested calories will be directed to muscle, rather than fat and/or attempt to physically affect gastric satiety by filling the stomach (Heber, 2003). And possibly spring from its anti water retention action (Duke, 2002). Or may be attributed to increase plasma leptin concentration which travels to the appetite control center in the brain and tells it to " stop eating " (Ebihara et al., 2001).

Severe hyperglycemia in diabetic rats recorded in the present work can be considered as a direct reflex to the marked hypoinsulinemia caused by the selective destructive cytotoxic effect of alloxan on the $\beta$-cells of the pancreas which has a direct effect on their membrane permeability by causing failure of ionic pumps and increased cells size. It also inhibits intracellular energy generation, insulin secretion and causes sudden activation of quiescent cells for a high level of protein synthesis and produced rapid and massive beta cell death which leading to a decrement in B-cells number (Majno and Joris, 1999).

The destructive effect of alloxan on B-cells may be also attributed to its ability to inhibit enzymes of the tricarboxylic acid cycle and $\mathrm{Ca}^{2+}$ dependent dehydrogenases in $\beta$-cell mitochondria, causing ATP deficiency, cessation of insulin production and cell necrosis (Shafrir, 2003).

The results of the present study also showed $\beta$-cells with vacuolated cytoplasm in the diabetic group. Vacuolation of the islet is the most prominent lesion associated with functional islet abnormality and development of hyperglycemia (Bolaffi $\boldsymbol{e t}$ al., 1986 and Kessler et a1.,1999). Also, the vacuolation may be due to the diabetogenic action of alloxan which induced highly reactive oxygen radicals, which are cytotoxic to $\beta$-cells (Fischer and Homburger, 1980). 
According to Yamamoto et al. (1981) and Ronald (1988) the fragmentation of nuclear DNA of pancreatic $\beta$-cells seems to be important for the development of diabetes and supposed to be resulted from the accumulation of superoxide or hydroxyl radicals in the $\beta$-cells.

Marles et al. (1995) suggested that, the hypoglycemic effect of some medicinal plants could be attributed to factors other than stimulation of insulin release only, e.g. their effect on the number and /or affinity of insulin receptors on target cells and the post-receptors of these cells.

Abdel Moneim et al. (1999a) reported that the hypoglycemic effect of Nigella sativa may be attributed to an increase in the islet numbers and to its effect on the time-course of glucose resorption from the intestine.

On the other hand, the Nigella sativa treated group showed insignificant change in beta cells number and diameter as compared to the normal group. This plant may have a stimulatory effect on the division of $\beta$-cells or may contain non-metabolizable 2-deoxy and 3-O-methylglucoses, which share the entry site block the diabetogenic action of alloxan and restore insulin production (Shafrir, 2003).

The significant hypoglycemic and insulinotropic effect induced in diabetic rats by such plants treatment may result from its effect on the time course of glucose resorption from the intestine. It also has an effect on peripheral tissues and regeneration of islet of Langerhans leading to lower blood glucose level. The treatment with Nigella sativa induced islet cells regeneration with increased number of $\beta$ cells (Abdel-Moneim et al., 1999 and ELDaly, 1994).

On the other hand, all treated groups recorded insignificant change in beta cells number and diameter as compared to normal group. These plants may have stimulatory effect on the division of beta cells to divided and /or contain nonmetabolizable 2-deoxy and 3-O-methylglucoses, which share the entry site block The diabetogenic action of alloxan and restore insulin production (Shafrir,2003). Augusti and Sheela (1996) mentioned that some plants exert their effect on beta cells through both protection of the already present beta cells due to their antioxidant effect and through stimulation of the beta cells to release insulin. In the present study it seems that the treated plants exert their action on the diabetic pancreas or due to close connection of admixture of islet cells, acinar cells and ductal epithelium which may resulted metaplastic change of acinar cells and ductal cells into islet cells under unknown stimulus (Hisoha and Horie, 1990).

In the present investigation, the treatment of diabetic rats with mixture and Boswellia carterii Birdw caused a significant hypoglycemic effect with a significant increase in serum insulin level and regenerated B-cells. In agreement with these findings Al-Awadi et al. (1988) reported that the mixture of (Nigella sativa, Aloe vera, Commiphora myrrha, Gum albunium and Ferula assa-foetida) is a potent hypoglycemic agent . The antidiabetic action of these plants extract may, at least partly, be mediated through decreased hepatic gluconeogenesis (AlAwadi et al., 1991). The decreasing of blood glucose level by the mixture and Boswellia carteii Birdw is secondary to enhanced insulin secretion, decreased insulin resistance and glycogen synthesis activation. it seems to have a direct action on insulin secretion through stimulation of secretion of the Golgi complex (Bever and Zahand, 1979) or it may stimulate insulin secretion through the B-cell receptor and possibly through a direct effect on intracellular calcium transport (Campbell et al., 1991).

Conclusions: The water extract of the mixture and each of the plants used appeared to be useful agents in reducing the hyperglycemia by increasing insulin level and regenerating beta cells of the pancreas. More studies on these plants must be done with different doses and for different periods before recommending their use.

\section{REFERENCES}

1. Abdel-Moneim, A.; El-Feki, M. and Salah, E. (1999 ): Effect of Nigella sativa, fish oil and gliclazide on alloxan-diabetic rats. IBiochemical and histo-pathological studies. J. Egypt. Ger. Sc. Zool., 23 (A): 237-265. 
2. Ajagaokar, S. S. (1979): Herbal drugs in the treatment of diabetes; IDF Bulletine, 14:10-17.

3. Al-hadar,A.;Agel,M. and Hasan,Z. (1993): Hypoglucemic effects of the volatile oil of Nigella Sativa seeds, Inbternational J pharmacy., 31 (2): 96-100.

4. Al-Awadi, F.M. and Shoukry, M. (1988): The lipid lowering effect of an antidiabetic plant extract. Acta. Diabetol. lat., 25:1-5.

5. Al-Awadi, F.; Farania, H. and Shamte, U.(1991): The effect of plants mixture on liver gluconeogensis in streptozotocin induced diabetic rats. Diabetes Research, 18:163-168.

6. Amos, A.F.; McCarty, D.J. and Zimmet, P. (1997): The rising global burden of diabetes and its complications, estimates and projections to the year 2000. Diabetes, medicine, (14 suppl.), 5:51-85.

7. Augusti, K. and Sheela, G. (1996): Theory and practice of histological techniques. $4^{\text {th }}$ edition. Churchill Living. Edinburgh and London.Pp.123.

8. Baily, C.J. and Flott, P.R. (1986): Antidiabetic drugs: New developments. Ind. Biotechnol., 6:139-142

9. Bever, B.O. and Zahnd, G.R. (1979): Plants with oral hypoglycemic action. Quart. J. Crude Drug Res., 34: 139-196.

10. Bolaffi, J.L.; Nowlain, R.E.; Grunz, L. and Grodsky, G.M. (1986): Progressive damage of cultured pancreatic islets after single early exposure to streptozotocin. Diabetes, 35:10271033.

11. Campbell, D.B.; Lavielle, R. and Mathan, C. (1991): The mode of action and clinical pharmacology of gliclazide. Diab. Res. Clin. Pract., 14 (2): 512-536.

12. Chevallier, A. (1996): The encyclopedia of medicinal plants. $1^{\text {st }}$ American ed. Pp.: 36, 237.

13. Duke, J.A. (2002): Hand book of medicinal Herbs. $2^{\text {nd }}$ ed.United states of America, Pp.: 15519.

14. Dunn, J.S.; Sheehan, H.L. and Moletchie, N.G.B. (1943): Necrosis of islets of Langerhans. Lancet, L: 484-487.

15. Ebihara, K.; Ogawa, Y. and Masuzaki, H;(2001): Transgenic over expression of liptin rescues insulin resistance and diabetes in a mouse model of Lipoatrophic diabetes. Diabetes., 50 (6): 1140

16. Fischer, L.J. and Homburger, S.A. (1980): Inhibition of alloxan action in isolated pancreatic islets by super oxide dismutase, catalase, and a metal chelator. Diabetes, 29: 213-216.

17. Ganong, W.F. (2003): Review of medical physiology, $23^{\text {rd }}$ ed., Lange med. Public, Chapter. 19:306-326.

18. Guyton, A.C. and Hall, J.E. (2000): Text book of medical physiology. Endocrinology and reproduction. Insulin, Glucagon and Diabetes Mellitus. $10^{\text {th }}$ ed. W.B. Sounders Company in U.S.A..
19. Halami, N.S. (1952): Differentiation of the two types of basophiles in an adenohyp-ophysis of the rat and the mouse. Stain Technology, 27: 61.

20. Heber, D. (2003): Herbal preparations for obesity: Are they useful?. Primcare., 30(2): 441-463.

21. Helal, E.; Hasan, M.; Mustafa, A. And AlKamel, A. (2003): Effect of Aloe vera extract on some physiological parameters in diabetic albino rats.The Egyptian Journal of Hospital Medicine vol., 12: 53-61.

22. Hisoka, M. and Horie, A. (1990): Unusual proliferation of the pancreatic endocrine cells in adults, suggestive of islet cell metaplasia. Sangyo. Ika. Daigaku. Zasshi.,12(4):429-437.(Abstract).

23. Kessler, J.; Hehmke, B.;Kloting, I. and Kohnert, K.D.(1999): Relatioship between the hisopathology of the endocrine-exocrine pancreas parenchyma and beta-cell function in the Chinese hamster CHIG / Han subline. Pancreas. 19(1): 8997.

24. Majno, G. and Joris, I. (1999): Cells, tissues and disease principles of general pathology. BraunBrunfield, Inc. U.S.A.

25. Marles, R.T. and Farnsworth, N.R. (1995): Antidiabetic plants and their active constituents Phytomedicine, 2: 137-189.

26. Marles, R.T. and Farnsworth, N.R. (1995): Antidiabetic plants and their active constituents. Phytomedicine, 2: 137-189.

27. Meral, I.; Yener, Z.; Kahraman, T. and Mert, N. (2001): Effect of Nigella sativa on glucose concentration, lipid peroxidation, anti-oxidant defence system and liver damage in experimentally induced diabetic rabbits. J. Vet. Med. A. Physiol. Pathol. Clin. Med.48(10)593-599.

28. Mossa, J. S. (1985): Photochemical and biological studies on Artmisia abyssinica, an antidiabetic herb used in Arabian folk medicine. Fitoterapia, 56 (5).

29. Rawi, S.M.; Abdel- Moneim, A.and Ahmed, O.M. (1996): Studies on the effect of garlic oil and glibenclamide on alloxan-diabetic rats. I. Hypoglycemic and histopathological effect. J. Union Arab Biol., 6(A): 121-142.

30. Rakieten, N.; Rakieten, M. L. and Nadkarni, M. V. (1963): Studies on the diabetogenic actions of streptozotocin. Cancer. Chemother., 29: 91-98.

31. Reeves, W.G. (1983): Insulin antibody determination: Theoretical and practical consideration. Diabetologia, 24:339-403.

32. Ronald, A.E. (1988): Animal models: an aid to the understanding to the etiology and pathogenesis of diabetes mellitus. Diabetes. Ann., 4:592-608.

33. Shafrir, E. (2003): Diabetes in animals: Contribution to the under standing of diabetes by study of its etiopathology in animal models. Bioennial review. SmithGordon, Pp.: 231-235.

34. Sokal, R. R. and Rahif, F. J. (1981): The principles and practical of statistic in Biological Research. $2^{\text {nd }}$ ed. Free man, W.H. company, San Frrancisco.

35. Tietz, N.W. (1986): Text book of clinical 
Structural Changes In The Pancreas Of.....

chemistry. W.B. Saunders Co., London,

Philadelphia, Pp.: 1389-1390

36. Yamamoto, H.; Uchigata, Y. and Okamoto, H. (1981): Streptozotocin and alloxan induced DNA strand breaks and poly (ADP-ribose) Synthetase in pancreatic islets. Nature, 294:284-286. 


\section{التغييرات التركيبية فى بنكرياس الجرذان المصابة بمرض السكر التجريبى

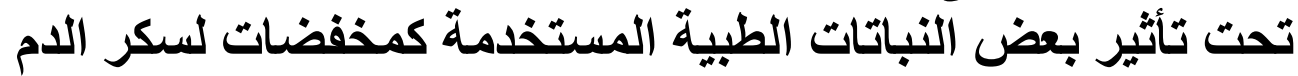

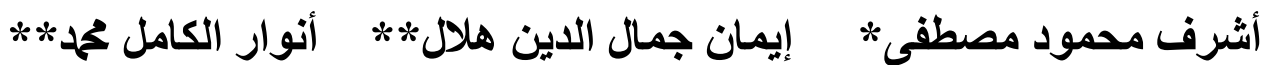

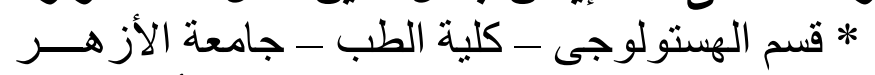

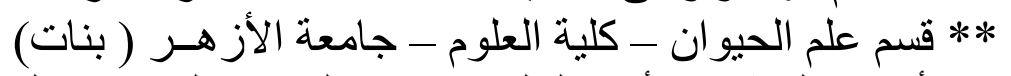

يعتبر مرض السكر من الأمر اض المنتشرة فى أنحاء العالم ويتسبب فى العديد من المضاعفات التى تصيب معظم

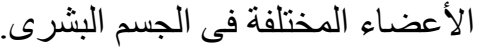

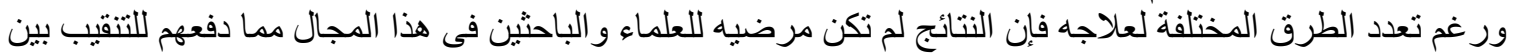

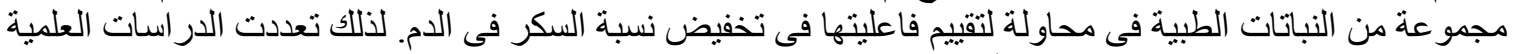

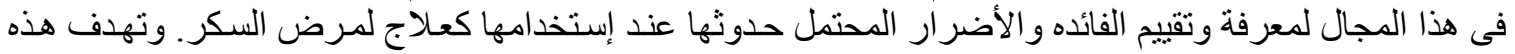

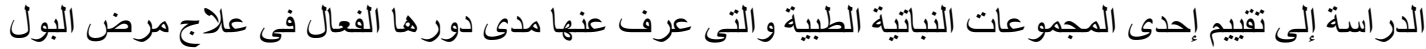

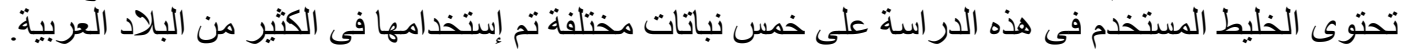

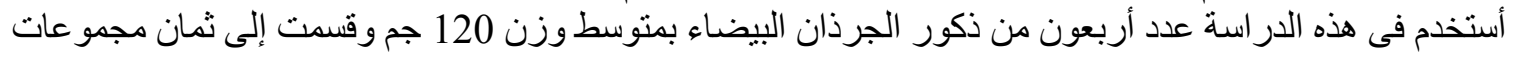

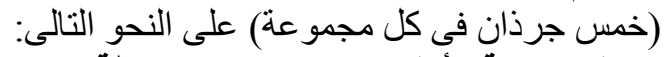

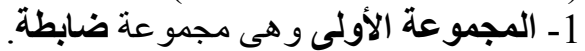

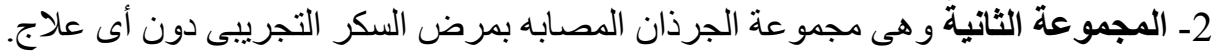

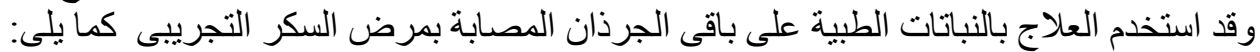

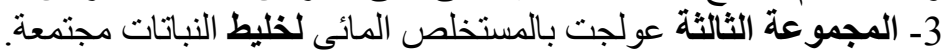
4- المجموعة الرابعة عولجت بالمستخلص المبائى لنبات حبة البركة البركة.

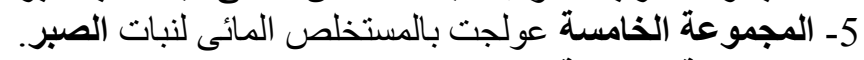

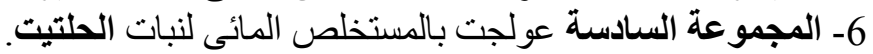

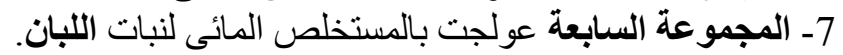

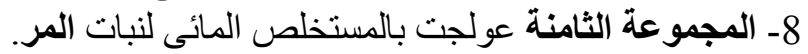

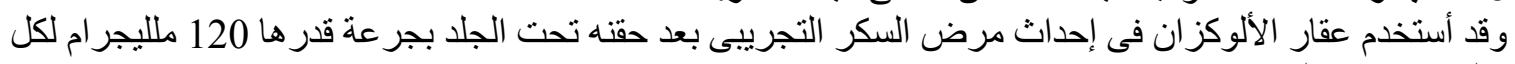

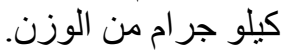
وقد تم تقييم نتائج هذا البحث فى إتجاهين رئيسين و وها التقييم المعكلى و التقييم النسيجى باستخدام عينات من

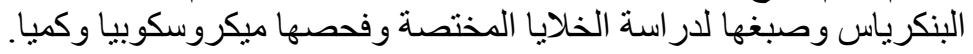

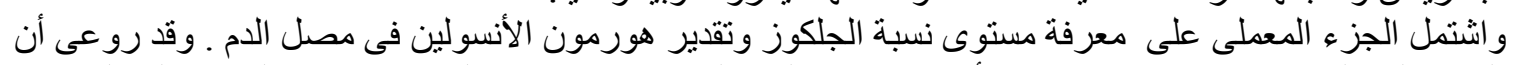

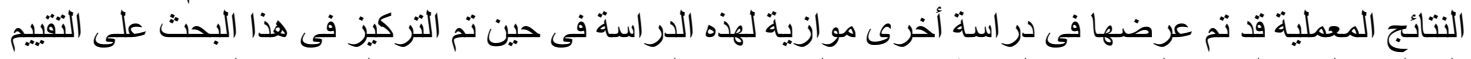

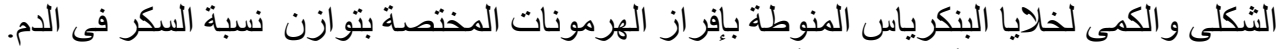

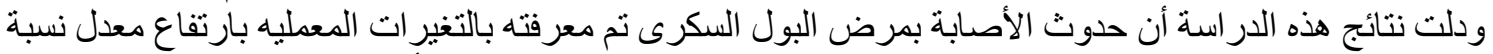

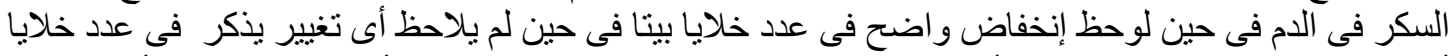
ألفا ودلتا بجانب زياده ملحوظه فى أقطار خلايا بيتا ولم توضح الدراسيا في من حدوث أى تغيير يذكر فى أقطار باقى خلى

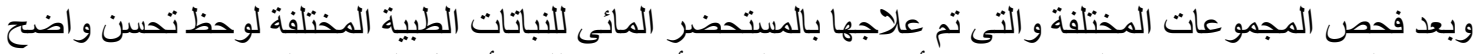

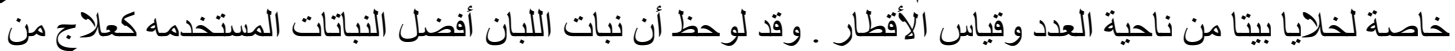

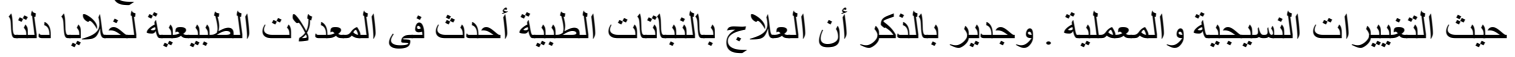

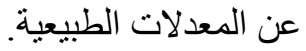

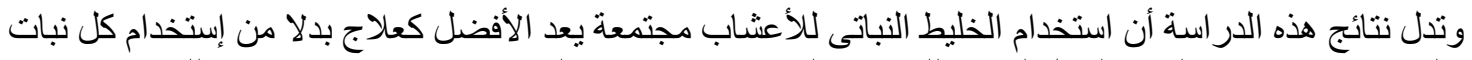

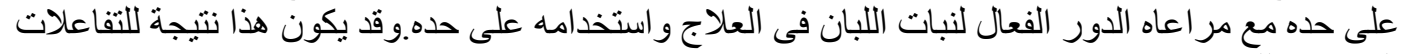

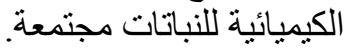

